\title{
Analisis Strategi Penanganan Pembiayaan Bermasalah Di Baitul Mal Wat Tamwil (BMT) Insani Sadabuan
}

\author{
Putri Maya Sari Harahap', Aswadi Lubis², Hamni Fadlillah Nasution3 \\ 1,2,3Institut Agama Islam Negeri Padangsidimpuan \\ JL. H.T. Rizal Nurdin Km 4,5 Sihitang Kota Padangsidimpuan-Sumatera Utara \\ Email: hamnifadlilah@gmail.com
}

\begin{abstract}
Abstrak
Pembiayaan bermasalah dapat mempengaruhi pendapatan BMT Insani Sadabuan. Dari hal itu dibutuhkan penanganan untuk mengatasi pembiayaan bermasalah tersebut. Tujuan penelitian ini adalah untuk dapat mengetahui strategi penanganan pembiayaan bermasalah yang dilakukan oleh Baitul Mal Wat Tamwil (BMT) Insani Sadabuan. Penelitian ini merupakan penelitian lapangan dengan pendekatan kualitatif. Hasil penelitian membahas tentang pembiayaan bermasalah yang disebabkan dua faktor yaitu faktor Internal (berasal dari pihak BMT Insani Sadabuan) dan faktor eksternal (berasal dari anggota). Penanganan pembiayaan bermasalah di BMT Insani Sadabuan dengan cara menghubungi anggota melalui telepon, penagihan langsung ke lokasi nasabah, memberikan modal Qardul Hasan, pembinaan kepada anggota, dan penjadwalan kembali.
\end{abstract}

Kata Kunci : Strategi Penanganan, Pembiayaan Bermasalah

\begin{abstract}
Non-performing financing can affect BMT Insani Sadabuan's income. From this it requires handling to overcome these problematic financing. The purpose of this research is to find out the strategy for handling problematic financing carried out by Baitul Mal Wat Tamwil (BMT) Insani Sadabuan. This research is a field research with a qualitative approach. The results of the study discuss about financing problems caused by two factors, namely internal factors (originating from BMT Insani Sadabuan) and external factors (originating from members). Handling problematic financing at BMT Insani Sadabuan by contacting members by telephone, direct billing to customer locations, providing Qardul Hasan capital, coaching members, and rescheduling.
\end{abstract}

Keywords: Handling Strategies, Problematic Financing 
89 Analisis Strategi Penanganan Pembiayaan Bermasalah Di Baitul Mal Wat Tamwil (BMT) Insani Sadabuan

\section{PENDAHULUAN}

Berdasarkan perkembangan zaman tidak semua masyarakat mampu memenuhi kebutuhan hidupnya, ada saatnya di mana masyarakat membutuhkan dana segera dalam waktu singkat untuk memenuhi kebutuhannya. Dengan permasalahan tersebut sangat diperlukan lembaga keuangan sebagai mediator dalam perekonomian modern antara kelompok masyarakat yang kelebihan dana dan kelompok masyarakat yang memerlukan dana, sehingga dapat terpenuhi kebutuhan hidup masyarakat.

Lembaga keuangan berperan sebagai lembaga intermediasi keuangan yang berproses pada penyerapan dana dari unit surplus ekonomi, baik sektor usaha, lembaga pemerintah maupun individu (rumah tangga) untuk penyediaan dana bagi unit ekonomi lain. Dalam operasionalnya lembaga keuangan dapat berbentuk lembaga keuangan konvensional dan lembaga keuangan syariah. Lembaga keuangan syariah dapat dibedakan menjadi lembaga keuangan depositori syariah yang disebut lembaga keuangan bank syariah dan lembaga keuangan non depositori yang disebut lembaga keuangan syariah bukan bank. Lembaga keuangan syariah yang tidak termasuk kategori bank syariah adalah seperti Baitul Mal Wat Tamwil (BMT) (Rodoni dan Hamid : 2007). Baitul Mal wat Tamwil (BMT) ialah balai usaha mandiri terpadu yang isinya berintikan baitul al-mal wa at-tamwil dengan kegiatan mengembangkan usaha-usaha produktif dan investasi dalam meningkatkan kualitas kegiatan ekonomi pengusaha kecil bawah dan kecil dengan antara lain mendorong kegiatan menabung dan menunjang pembiayaan kegiatan ekonominya. Selain itu, BMT juga bisa menerima titipan zakat, infak, dan sedekah lalu menyalurkannya sesuai dengan peraturan dan amanat. BMT adalah lembaga ekonomi atau keuangan syariah non perbankan yang sifatnya informal karena lembaga ini didirikan oleh Kelompok Swadaya Masyarakat (KSM) yang berbeda dengan lembaga keuangan perbankan dan lembaga keuangan formal lainnya.

BMT bersifat terbuka, independen, berorientasi pada pengembangan tabungan dan pembiayaan untuk mendukung bisnis ekonomi yang produktif bagi anggota dan kesejahteraan sosial masyarakat sekitar, terutama usaha mikro dan fakir miskin. Peran BMT di masyarakat sebagai berikut motor penggerak ekonomi dan sosial masyarakat banyak, ujung tombak pelaksanaan sistem ekonomi syariah, penghubung antara kaum aghnia (kaya) dan kaum duafa (miskin), sarana pendidikan informal untuk mewujudkan prinsip hidup yang barakah, ahsanu 'amala dan salaam melalui spiritual communication dengan dzikir qalbiyah ilahiyah. 
Beberapa fungsi dijalankan BMT di antaranya meliputi meningkatkan kualitas SDM anggota, pengurus, dan pengelola menjadi lebih profesional, salam, dan amanah sehingga semakin utuh dan tangguh dalam berjuang dan berusaha menghadapi tantangan global, mengorganisasi dan memobilisasi dana yang dimiliki oleh masyarakat dapat termanfaatkan secara optimal di dalam dan di luar organisasi untuk kepentingan rakyat banyak, mengembangkan kesempatan kerja, mengukuhkan dan meningkatkan kualitas usaha dan pasar produk-produk anggota, memperkuat dan meningkatkan kualitas lembaga-lembaga ekonomi dan sosial rakyat banyak (salman : 2012).

Secara konseptual BMT memiliki dua fungsi, yaitu baitul mal dan baitut tamwil. Baitul mal, Bait artinya rumah sedangkan al mal artinya harta, penjelasannya bahwa baitul mal berfungsi menerima titipan dana ZIS (zakat, infak, dan sedekah) serta mengoptimalkan distribusinya dengan memberikan santunan kepada yang berhak (ashnaf) sesuai dengan peraturan dan amanat yang diterima. Baitut tamwil, Bait artinya rumah sedangkan at tamwil artinya pengembangan harta, penjelasannya bahwa baitut tamwil berfungsi melakukan kegiatan pengembangan usaha-usaha produktif dan investasi dalam meningkatkan kualitas ekonomi pengusaha mikro dan kecil, terutama dengan mendorong kegiatan menabung dan menunjang pembiayaan kegiatan ekonomi.

Baitul Maal wat Tamwil (BMT) hadir sebagai wahana transformasi ekonomi para aghniya (pemilik uang) kepada dhuafa, pedagang kecil yang membutuhkan modal usaha. BMT merupakan lembaga keuangan syariah yang menerima dan mendistribusikan dana Islam yang berupa zakat, infaq, shadaqah, hibah dan wakaf yang dipercayakan kepadanya untuk disalurkan kepada yang berhak. BMT adalah lembaga keuangan yang bersifat komersial berdasarkan akad/perjanjian simpan pinjam, wadiah, mudharabah dan penyertaan (syirkah) kepada masyarakat untuk kegiatan usaha yang bersifat produktif dengan sistem bagi hasil.

BMT dibangun dengan basis keummatan, karena dibentuk dari, oleh dan untuk masyarakat. Solusi pemberdayan usaha kecil dan menengah. Landasan hukum cukup kuat (UU No. 7/1992, UU No. 10/1998), menyelenggarakan kegiatan usaha pelayanan dana jasa keuangan dalam skala kecil dan menengah. UU No. 10/1998, pasal 6, lembaga keuangan konvensional dapat menyelenggarakan unit pelayanan syariah seperti bank syariah dengan menggunakan prinsip bagi hasil (Profit and loss sharing) secara dual banking system. Dikategorikan koperasi syariah, lembaga ekonomi yang berfungsi untuk menarik, mengelola dan menyalurkan dana dari, oleh dan 
91 Analisis Strategi Penanganan Pembiayaan Bermasalah Di Baitul Mal Wat Tamwil (BMT) Insani Sadabuan

untuk masyarakat. Sisi Yuridis UU No. 7/1992 tidak termasuk lembaga keuangan bank. Fungsi BMT tidak hanya profit oriented, tetapi juga social oriented.

Kegiatan BMT adalah mengembangkan usaha-usaha produktif dan investasi dalam meningkatkan kualitas kegiatan ekonomi pengusaha makro dan kecil, antara lain mendorong kegiatan menabung dan pembiayaan kegiatan ekonominya (Rodoni dan Hamid : 2007) Sebagai salah satu lembaga keuangan yang berorientasi pada bisnis, Baitul Mal Wat tamwil (BMT) selalu menawarkan produk-produk baru terhadap calon anggotanya. Salah satu produk yang sering diberikan oleh pihak BMT adalah produk pembiayaan (Kurniawan : 2017). Penyaluran dana dalam bentuk pembiayaan didasarkan pada kepercayaan yang diberikan oleh pemilik dana kepada pengguna dana. Sehingga penerima pembiayaan berkewajiban untuk mengembalikan pembiayaan yang telah diterimanya sesuai dengan jangka waktu yang telah diperjanjikan dalam akad pembiayaan (Ismail : 2011)

Berdasarkan keterangan yang diperoleh langsung, Menurut Ibu Enni Afrida Santi sebagai Sekretaris BMT Insani Sadabuan Kota Padangsidimpuan mengatakan bahwa Produk pembiayaan merupakan produk yang banyak digunakan oleh para nasabah dibandingkan dengan produk lainnya, karena dengan produk pembiayaan ini perekonomian nasabah yang menjadi anggota di BMT Insani dapat terbantu dan menjadi lebih baik lagi sebab usaha yang dikelolanya dari pembiayaan yang disalurkan oleh BMT Insani Sadabuan Kota Padangsidimpuan. Tetapi tidak sedikit pula nasabah BMT Insani Sadabuan yang tidak dapat mengembalikan kewajibannya berdasarkan waktu yang telah disepakati diawal akadnya sehingga terjadi pembiayaan bermasalah.

Berikut ini perkembangan jumlah nasabah dan pembiayaan bermasalah pada Baitul Mal Wat Tamwil (BMT) Insani Sadabuan Kota Padangsidimpuan lima tahun terakhir: 
Tabel 1

Jumlah Nasabah Pembiayaan dan Jumlah Nasabah Pembiayaan Bermasalah di Baitul Mal Wat Tamwil (BMT) Insani Sadabuan Kota Padangsidimpuan Tahun 2014-2018

\begin{tabular}{|l|l|l|l|l|}
\hline Tahun & $\begin{array}{l}\text { Jumlah } \\
\text { Nasabah } \\
\text { Pembiayaan }\end{array}$ & $\begin{array}{l}\text { Total } \\
\text { Pembiayaan }\end{array}$ & $\begin{array}{l}\text { Jumlah } \\
\text { Nasabah } \\
\text { Pembiayaan } \\
\text { Bermasalah }\end{array}$ & $\begin{array}{l}\text { Total } \\
\text { Pembiayaan } \\
\text { Bermasalah }\end{array}$ \\
\hline 2014 & 118 Orang & Rp. 477.340 .850 & 19 Orang & Rp. 76.00o.0oo \\
\hline 2015 & 119 Orang & Rp. 541.699 .350 & 25 Orang & Rp. 92.350.000 \\
\hline 2016 & 115 Orang & Rp. 505.038 .350 & 32 Orang & Rp. 54.000.000 \\
\hline 2017 & 105 Orang & Rp. 446.228 .850 & 30 Orang & Rp. 93.452.000 \\
\hline 2018 & 97 Orang & Rp. 352.808 .350 & 17 Orang & Rp. 34.150.000 \\
\hline
\end{tabular}

Sumber: Baitul Maal Wat Tamwil (BMT) Insani Sadabuan Kota Padangsidimpuan

Dari tabel 1 dapat dilihat total pembiayaan bermasalah pada tahun 2014 Rp. 76.00o.ooo, Tahun 2015 total pembiayaan bermasalah meningkat sebesar 17,04\%, Tahun 2016 total pembiayaan bermasalah menurun sebesar 10,69\%, Tahun 2017 total pembiayaan bermasalah meningkat sebesar 20,9\%, Tahun 2018 total pembiayaan bermasalah menurun sebesar 9,67\%.

Pembiayaan bermasalah merupakan indikasi terdapat tingkat penurunan atas kewajiban yang diberikan oleh pihak BMT Insani Sadabuan kepada nasabah. Permasalahan tersebut sebagai salah satu sarana dalam menetapkan strategi usaha diwaktu kedepannya. BMT yang tidak atau kurang sehat menunjukkan bahwa ada ketidaksesuaian dalam pengelolaannya dan apabila tidak segera diantisipasi BMT yang kurang sehat akan mengalami banyak kesulitan dalam mekanisme operasionalnya sebelum akhirnya terpuruk dan mengalami kerugian (Nornita : 2012). Pembiayaan bermasalah dilihat dari segi produktivitasnya (performance) yaitu dalam kaitannya dengan kemampuan menghasilkan pendapatan bagi bank, sudah berkurang atau menurun dan bahkan mungkin sudah tidak ada lagi. Dengan demikian dapat disimpulkan bahwa pembiayaan bermasalah adalah pembiayaan yang kualitasnya berada di dalam golongan kurang lancar, diragukan, dan macet (Djamil : 2012).

Hasil wawancara dengan Ibu Enni Afrida Santi Sekretaris BMT Insani Sadabuan Kota Padangsidimpuan, beliau mengatakan "Perlu adanya strategi penanganan untuk mencegah JISFIM: Journal of Islamic Social Finance Management, Volume 1, No 1 Tahun 2020 http://jurnal.iain-padangsidimpuan.ac.id/index.php/JISFIM 
93 Analisis Strategi Penanganan Pembiayaan Bermasalah Di Baitul Mal Wat Tamwil (B M T) Insani Sadabuan

ataupun mengurangi terjadinya kerugian pada BMT Insani Sadabuan”. Sebab, semakin besar pembiayaan bermasalah, maka semakin besar jumlah cadangan yang harus disediakan, dan semakin besar pula tanggungan untuk mengadakan dana cadangan kerugian tersebut, karena kerugian yang ditanggung akan mengurangi modal sendiri (Komalasari : 2016).

Menurut (Nawfalsky Bagis Muhammad Karangpuang : 2017) dengan judul strategi penanganan pembiayaan murabahah bermasalah pada baitul mal wat tamwil (BMT) mekar da'wah pembiayaan adalah pemberian bantuan uang atau tagihan yang nilainya dapat diukur dengan uang, misalnya bank atau lembaga keuangan yang membiayai pembeliam suatu barang. Kemudian adanya kesepakatan antara kedua belah pihak (yang membiayai dan yang dibiayai) dalam sebuah perjanjian yang telah disepakati, yang mana dalam perjanjian ini terdapat hak dan kewajiban masing-masing pihak, termasuk jangka waktu serta perolehan keuntungan yang telah disetujui bersama berdasarkan kedua belah pihak.

Cara menangani pembiyaan bermasalah dilakukan dengan beberapa metode, yaitu Restructuring, Salah satu bentuk upaya penyelamatan yang lazim dilakukan oleh bank terhadap nasabah yang mulai mengalami kesulitan adalah restrukturisasi pembiayaan. Restrukturisasi pembiayaan merupakan upaya perbaikan yang dilakukan oleh bank terhadap nasabah pembiayaan yang berpotensi atau mengalami kesulitan memenuhi kewajiban. Restrukturisasi dapat dilakukan antara lain melalui perpanjangan waktu pembiayaan, pengurangan tunggakan bunga pembiayaan, pengurangan tunggakan pokok pembiayaan, penambahan fasilitas pembiayaan, atau konversi pembiayaan menjadi penyertaan modal sementara (IBI : 2015).

Rescheduling, Strategi atau langkah penyelamatan kredit dengan melakukan perubahan jangka waktu pelunasan, jumlah setoran pelunasan, dan atau pembayaran bunga. Dalam hal ini si debitur diberikan keringanan dalam masalah jangka waktu kredit pembayaran kredit, misalnya perpanjangan waktu kredit dari 6 bulan menjadi satu tahun sehingga si debitur mempunyai waktu yang lebih lama untuk mengembalikannya.

Reconditioning, Reconditioning maksudnya adalah bank mengubah berbagai persyaratan yang ada seperti kapitalisasi bunga, yaitu bunga dijadikan hutang pokok, penundaan pembayaran bunga sampai waktu tertentu, penurunan suku bunga, pembebasan bunga. Kombinasi, merupakan kombinasi dari ketiga jenis yang di atas. Seorang nasabah dapat saja diselamatkan dengan kombinasi antara Rescheduling dengan Retructuring, misalnya jangka waktu diperpanjang pembayaran bunga ditunda atau Reconditioning dengan Rescheduling misalnya jangka waktu diperpanjang modal ditambah. Penyitaan Jaminan, merupakan jalan terakhir JISFIM: Journal of Islamic Social Finance Management, Volume 1, No 1 Tahun 2020 http://jurnal.iain-padangsidimpuan.ac.id/index.php/JISFIM 
apabila nasabah sudah benar-benar tidak punya iktikad baik ataupun sudah tidak mampu lagi untuk membayar semua hutang-hutangnya (Kasmir : 2008).

\section{METODE PENELITIAN}

Lokasi penelitian adalah Baitul Mal Wat Tamwil (BMT) Insani, Jln. Sudirman, Kompleks Pasar Inpres Sadabuan, No. 22 Padangsidimpuan Utara, Kota Padangsidimpuan. Jenis penelitian ini ialah kualitatif yang bersifat analisis deskriptif, yaitu penelitian yang menggambarkan data dan informasi yang berlandaskan fakta-fakta yang diperoleh dari lapangan mengenai penerapan strategi penanganan pembiayaan bermasalah pada BMT Insani Sadabuan Kota Padangsidimpuan.

Unit analisis merupakan suatu satuan tertentu yang diperhitungkan sebagai subjek penelitian. Dalam hal ini, subjek penelitian dapat berupa benda, manusia atau dalam penelitian lain berupa sekolah, lembaga, bank atau desa. Dalam menganalisa banyaknya data satuan menunjukkan banyak subjek penelitian. Subjek penelitian adalah subjek yang dituju untuk diteliti oleh peneliti (Arikunto : 2002). Dalam penelitian ini yang menjadi subjek penelitian adalah pegawai atau karyawan di BMT Insani Sadabuan Kota Padangsidimpuan dan nasabah pembiayaan bermasalah pada tahun 2018 yaitu sebanyak 17 orang.

Teknik Pengumpulan Data, meliputi observasi yang dilakukan dengan mengadakan pengamatan langsung kelapangan dengan mendatangi narasumber yakni pada BMT Insani Sadabuan Kota Padangsidimpuan, hal ini digunakan untuk mengetahui keadaan sebenarnya yang terjadi pada lokasi penelitian berkaitan dengan strategi penanganan pembiayaan bermasalah. Kemudian dilakukan wawancara atau interview adalah suatu bentuk komunikasi verbal, jadi semacam percakapan yang bertujuan memperoleh informasi (Nasution : 2003), dimana wawancara adalah bentuk komunikasi antara dua orang, melibatkan seseorang yang ingin memperoleh informasi dari seseorang lainnya dengan mengajukan pertanyaan-pertanyaan, berdasarkan tujuan tertentu (Mulyana : 2006). Peneliti mengadakan wawancara dengan para fungsional BMT Insani Sadabuan Kota Padangsidimpuan yang dianggap berkompoten dan representatif dengan masalah untuk memperoleh informasi mengenai strategi penanganan pembiayaan bermasalah pada BMT Insani Sadabuan Kota Padangsidimpuan. Dalam penelitian ini wawancara yang digunakan peneliti adalah wawancara semi terstruktur. Pedoman wawancara ini disusun secara terperinci, akan tetapi pewawancara masih menggali data lagi lebih dalam selain yang sudah tercantum dalam pedoman wawancara (Kholil : 2006). Dan teknik http://jurnal.iain-padangsidimpuan.ac.id/index.php/JISFIM 
95 Analisis Strategi Penanganan Pembiayaan Bermasalah Di Baitul Mal Wat Tamwil (BMT) Insani Sadabuan

dokumentasi dilakukan dengan cara mengumpulkan data dan mempelajari data-data yang ada, yang berkaitan dengan pembahasan skripsi ini melalui buku, artikel, brosur, majalah, surat kabar, internet dan media lainnya yang berhubungan dengan pokok pembahasan.

Teknik pengolahan dan analisis data, analisis data dalam penelitian merupakan suatu kegiatan yang sangat penting dan memerlukan ketelitian serta kekritisan dari peneliti (Zuriah : 2006). Metode analisis data adalah suatu metode yang digunakan untuk mengelolah hasil penelitian guna memperoleh suatu kesimpulan. Dengan melihat landasan penelitian teoritis, maka teknik analisis data yang digunakan dalam penelitian ini adalah Analisis Kualitatif Deskriptif. Dalam penelitian ini analisis yang digunakan untuk mengetahui strategi penanganan pembiayaan bermasalah di Baitul Mal Wat Tamwil Sadabuan Kota Padangsidimpuan.

Tujuan analisis data adalah proses mengatur urutan data, mengorganisasikannya ke dalam suatu pola, kategori dan satuan uraian dasar. Pekerjaan analisis data dalam hal ini ialah mengatur, mengurutkan, mengelompokkan, memberikan kode, dan mengategorikannya bertujuan menemukan tema dan hipotesis kerja yang akhirnya diangkat menjadi teori substantif (Moleong : 2004). Adapun aktivitas dalam analisis data yaitu reduksi data (data reduction), yaitu pengolahan data mulai dari editing, koding, hingga tabulasi data yang mencakup kegiatan mengiktiarkan hasil pengumpulan data selengkap mungkin dan memilihnya ke dalam satuan konsep tertentu, kategori tertentu, atau tema tertentu, penyajian data (Display data), Hasil reduksi data diorganisasikan sehingga terlihat sosoknya secara lebih utuh, concluction drawing and verification, pembuatan tabel atau diagram berbentuk sketsa, sinopsis, matriks atau bentukbentuk lain ataupun jenis reduksi data yang telah diorganisasikan untuk memudahkan pemaparan dan penegasan kesimpulan (Bungin : 2003).

Teknik pengecekan keabsahan data menggunakan Ketekunan Pengamatan bermaksud menemukan ciri-ciri dan unsur-unsur dalam situasi yang sangat relevan dengan persoalan atau isu yang sedang dicari dan kemudian memusatkan diri pada hal-hal tersebut secara terperinci. Hal ini berarti bahwa peneliti hendaknya mengadakan pengamatan dengan teliti dan rinci secara berkesinambungan terhadap faktor-faktor yang menonjol, kemudian ditelaah secara rinci sampai pada suatu faktor yang ditelaah sudah dipahami dengan cara yang biasa (Moleong : 2004). 


\section{HASIL DAN PEMBAHASAN}

\section{Faktor-Faktor Penyebab Terjadinya Pembiayaan Bermasalah Di BMT Insani Kota Padangsidimpuan}

Pembiayaan bermasalah disebabkan karena nasabah ataupun anggotanya tidak dapat memenuhi kewajiban kepada pihak BMT Insani Sadabuan Kota Padangsidimpuan yang disebabkan karena faktor-faktor Internal dan eksternal yang dialami oleh BMT Insani Sadabuan. Faktor penyebab terjadinya pembiayaan bermasalah tersebut yaitu Faktor Internal, faktor internal ini adalah faktor yang menyebabkan pembiayaan bermasalah dari BMT Insani Sadabuan itu sendiri. Berikut ini adalah faktor internal yang menjadi penyebab terjadinya pembiayaan bermasalah tersebut yaitu kurang pengawasan, dalam hal ini, kemampuan petugas BMT Insani Sadabuan dalam menganalisa calon nasabah ataupun anggota kurang baik atau juga karena kemampuan petugas dalam menganalisa karakter dan usaha calon nasabahnya kurang akurat sehingga menimbulkan pembiayaan yang bermasalah. Kurangnya pengawasan yang diterapkan oleh BMT Insani Sadabuan Kota Padangsidimpuan akan menyebabkan terjadinya pembiayaan bermasalah yang meningkat dan berakibat kerugian. Untuk itu diperlukan adanya pengawasan terhadap anggota, seperti; pihak BMT Insani Sadabuan melakukan pemantauan terhadap usaha anggota yang menerima pembiayaan, agar anggota mampu melunasi kewajibannya tepat waktu.

Kurang SDM (Sumber Daya Manusia), saat ini belum ada tim khusus yang menangani fungsi pembiayaan karena Staf pegawai saling bahu membahu untuk semua operasional BMT Insani Sadabuan tidak ada yang khusus menangani pembiayaan sehingga kurangnya pantauan terhadap nasabah yang menjadi anggota pembiayaan, kurangnya sumber daya manusia yang bertugas khusus dalam pembiayaan tersebut menyebabkan para anggotanya berbuat sesuka hatinya dalam melunasi pembiayaaan yang diberikan kepadanya sehingga terjadi pembiayaan bermasalah. SDM (Sumber Daya Manusia) di BMT Insani Sadabuan hanya berjumlah 3 orang yaitu Ketua, Sekretaris dan Bendahara untuk menangani anggota. Kurangnya sumber daya manusia tersebut merupakan faktor terjadinya pembiayaan bermasalah di BMT Insani. Karena seharusnya SDM yang terdapat dalam BMT itu terdiri dari Manajer Umum, Manajer Keuangan, Manaejer Administrasi, Manajer Pembiayaan, dan Kasir beserta tugasnya masing-masing. Apabila SDM (Sumber daya manusia) terpenuhi maka anggota pembiayaan akan merasa adanya pengawasan terhadap usaha yang dikelolahnya. Sehingga nasabah ataupun anggota dapat menyampaikan laporan keuangannya kepada pihak BMT Insani Sadabuan secara teratur, dan terhindar dari pembiayaan bermasalah.

JISFIM: Journal of Islamic Social Finance Management, Volume 1, No 1 Tahun 2020 http://jurnal.iain-padangsidimpuan.ac.id/index.php/JISFIM 
97 Analisis Strategi Penanganan Pembiayaan Bermasalah Di Baitul Mal Wat Tamwil (B M T) Insani Sadabuan

Faktor Eksternal, faktor eksternal ini memiliki persentase peran yang cukup besar karena faktor eksternal lebih sering terjadi pada BMT Insani Sadabuan Kota Padangsidimpuan. Faktor eksternal ini merupakan faktor-faktor yang berasal dari luar BMT Insani Sadabuan atau dari para anggota pembiayaannya. Berikut adalah faktor ekternal yang menyebabkan terjadinya pembiayaan bermasalah pada BMT Insani Sadabuan Kota Padangsidimpuan, yaitu keadaan ekonomi, salah satu penyebab pembiayaan bermasalah di BMT Insani Sadabuan yaitu disebabkan oleh faktor ekonomi karena perekonomian para anggotanya tidak selalu berada dalam tingkat yang tinggi akan tetapi mengalami siklus naik turun sehingga menyebabkan para anggotanya tidak membayar kewajibannya sesuai dengan jangka waktu yang telah disepakati di awal akadnya. Seperti hasil wawancara yang diperoleh dari salah satu pegawai BMT Insani Sadabuan oleh Ibu Elfi S Harahap mengatakan "Kendaraan becak di Sidimpuan sangat banyak akan tetapi penumpangnya sangat sedikit, sehingga anggota yang menjadi supir becak tersebut tidak memperoleh target yang diharapkan dan tidak mencukupi untuk membayar kewajibannya”.

Pernyataan dari pihak BMT diperkuat oleh pihak anggota pembiayaan yang mengalami penuruan usaha. Berikut hasil wawacara dengan salah satu anggota pembiayaan Bapak Ali Ahmad beliau mengatakan "Pendapatan yang diperoleh dari hasil usaha ini tidak sesuai dengan target yang diharapkan sehingga tidak mampu melunasi pembiayaan yang disalurkan dengan tepat waktu. Karena pendapatan yang diperoleh digunakan untuk biaya sewa rumah, biaya tagihan listrik dan biaya sekolah anak. Selain pernyataan tersebut hasil wawancara peneliti dengan beberapa nasabah lainnya diperoleh kesimpulan bahwa keadaan ekonomi yang tidak tetap memang merupakan penyebab nasabah tidak mampu melunasi kewajibannya berdasarkan jangka waktu yang disepakti. Banyaknya persaingan dalam usaha juga merupakan turunnya perekonomian anggota sesuai dengan pernyataan yang diperoleh dari Bapak Ibrahim Harahap beliau mengatakan bahwa "Masyarakat penumpang becak sudah mulai berkurang, karena adanya angkutan lain dan masyarakat lebih memilih untuk menggunakan kenderaan sendiri, sehingga kami para supir becak harus mengantri panjang untuk menunggu penumpang, terkadang juga masyarakat memilih untuk memakai kenderaan becak pada saat hujan turun saja, sehingga menyebabkan pendapatan yang diperoleh tersebut tidak sesuai target sehingga tidak mampu membayar kewajiban tepat waktu”.

Sesuai dengan pernyataan tersebut di atas dapat disimpulkan bahwa faktor terbesar terjadinya pembiayaan bermasalah di BMT Insani Sadabuan Kota Padangsidimpuan yaitu disebabkan oleh faktor ekonomi yang tidak tetap dan pendapatan yang tidak sesuai dengan target JISFIM: Journal of Islamic Social Finance Management, Volume 1, No 1 Tahun 2020 http://jurnal.iain-padangsidimpuan.ac.id/index.php/JISFIM 
yang diharapkan. Sedangkan kebutuhan pokok lainnya harus dipenuhi dengan kondisi perekonomian yang tidak baik, Sehingga nasabah tidak mampu melunasi kewajibannya pada waktu yang tepat.

Permasalahan Cuaca, cuaca yang tidak tetap merupakan penyebab para anggota pembiayaan tidak mampu membayar kewajibannya sesuai dengan jangka waktu yang telah disepakati. Seperti yang disampaikan oleh Ibu Elfi S Harahap Bendahara BMT Insani Sadabuan Kota Padangsidimpuan mengatakan "Pedagang ikan saleh yang hanya bagus berdagang pada saat cuaca cerah dagangannya tidak akan habis terjual pada saat turun hujan terus-menerus, karena hujan tersebut menyebabkan ikan yang akan dijualkan menjadi lembab, pada akhirnya ikan yang lembab tersebut busuk dan tidak dapat dijual lagi. Sehingga anggota BMT Insani Sadabuan yang berdagang tersebut tidak memperoleh keuntungan sesuai dengan target yang diharapkan yang menyebabkan pembiayaan bermasalah, karena ia tidak mampu membayar kewajibannya berdasarkan waktu yang telah disepakati”.

Berdasarkan hasil wawancara dengan Ibu Darlina dan Ibu Arwani Harahap beliau mengatakan bahwa "Penyebab ketidak mampuan dalam membayar pembiayaan berdasarkan jangka waktu yang telah disepakati adalah karena faktor cuaca yang tidak mendukung yang menyebabkan pendapatan yang diperoleh dapat menurun sehingga tidak mampu membayar pembiayaan yang diberikan tepat waktu.”

Analisa hasil wawancara tersebut bahwa pernyataan yang diberikan oleh pihak BMT Insani Sadabuan sesuai dengan hasil wawancara dari nasabahnya. Untuk itu pembinaan kepada anggota dilakukan agar usaha yang terkendala karena faktor cuaca dapat tekendali dengan memberikan pembinaan untuk membuka usaha lain apabila cuaca hujan turun terus menerus, dengan tujuan agar anggota tersebut dapat memperoleh pendapatan meskipun cuaca turun hujan, sehingga anggota tersebut mampu membayar kewajiban yang diberikan kepadanya tepat waktu.

Musibah, faktor musibah merupakan sebuah hal diluar nalar manusia. Sehingga anggota pembiayaan yang terkena musibah belum bisa memenuhi kewajibannya terhadap BMT Insani Sadabuan Kota Padangsidimpuan, bukan atas dasar karena adanya unsur kesengajaan. Musibah yang dialami anggota bisa disebabkan oleh berbagai macam hal, misalnya bencana alam, harta bendanya hilang, dan jenis musibah lainnya. Berdasarkan hasil wawancara dengan Bapak Sutan Simatupang dan Ibu Tika mengatakan bahwa "Musibah yang dialami merupakan faktor penyebab ketidak mampuan dalam membayar pembiayaan yang disalurkan karena keterpurukan yang

JISFIM: Journal of Islamic Social Finance Management, Volume 1, No 1 Tahun 2020 http://jurnal.iain-padangsidimpuan.ac.id/index.php/JISFIM 
99 Analisis Strategi Penanganan Pembiayaan Bermasalah Di Baitul Mal Wat Tamwil (B M T) Insani Sadabuan

dirasakan. Akibatnya tidak bisa berusaha dalam beberapa waktu sehingga tidak memperoleh pendapatan untuk membayar pembiayaan tersebut”.

Apabila musibah tersebut dialami anggota, maka pihak BMT Insani Sadabuan maklum atas hal tersebut, karena musibah tersebut tidak terduga dan tidak dapat di prediksi, dan pihak BMT Insani Sadabuan berusaha memberikan motivasi kepada anggota yang terkena musibah tersebut, dengan tujuan anggota pembiayaan tersebut dapat bangkit dari keterpurukan yang dialaminya, dengan harapan anggota tersebut dapat kembali berusaha seperti biasanya agar bisa melunasi pembiayaan yang diberikan kepadanya sehingga BMT Insani Sadabuan tidak merugi.

Berdasarkan pernyataan tersebut dapat diketahui bahwa musibah yang dialami nasabah pembiayaan merupakan penyebab terjadinya pembiayaan bermasalah. Sehingga diperlukan adanya penanganan yang dilakukan BMT Insani Sadabuan untuk mengembalikan semangat para nasabah untuk dapat menjalankan usahanya kembali agar dapat memperoleh pendapatan sesuai dengan target yang diharapkan, dengan tujuan supaya dapat melunasi pembiayaan yang disalurkan tepat waktu dan terhindar dari pembiayaan bermasalah yang dapat merugikan BMT Insani Sadabuan.

\section{Strategi Penanganan yang Dilakukan BMT Insani Sadabuan Kota Padangsidimpuan Dalam Mengatasi Pembiayaan Bermasalah}

Penyelamatan pembiayaan bermasalah ataupun strategi penanganan pembiayaan bermasalaah merupakan bagian yang tidak dapat dihindari dalam proses pembiayaan di dalam situasi lembaga keuangan maupun non lembaga keuangan. Maka strategi penaganan pembiayaan bermasalah merupakan suatu hal yang sangat penting untuk dilakukan. Oleh karena itu, jika diketahui adanya gejala suatu pembiayaan yang berpotensi bermasalah, maka pihak BMT Insani Sadabuan segera mengambil langkah penyelamatan sebelum masalah tersebut menimbulkan kerugian. Adapun strategi penanganan yang dilakukan oleh pihak BMT Insani Sadabuan Kota Padangsidimpuan dalam menangani pembiayaan bermasalah tersebut antara lain yaitu, menghubungi anggota melalui telepon, apabila terdapat anggota yang belum berhadir untuk melunasi pembiayaan yang diberikan kepadanya di hari yang telah disepakati, maka pegawai BMT Insani Sadabuan menghubunginya melalui via telepon dengan tujuan untuk mengingatkan anggota agar segera melunasi kewajibannya.

Penagihan langsung ke lokasi nasabah, apabila nasabah pembiayaan belum juga melunasi kewajibannya berdasarkan waktu yang telah disepakati, maka pegawai BMT Insani Sadabuan Kota Padangsidimpuan langsung mendatangi lokasi nasabah yang pembiayaannya bermasalah JISFIM: Journal of Islamic Social Finance Management, Volume 1, No 1 Tahun 2020 http://jurnal.iain-padangsidimpuan.ac.id/index.php/JISFIM 
tersebut dengan tujuan menyurvei anggota tersebut untuk menanyakan kendala yang dihadapi oleh anggota. Apabila ia menghadapi kendala yang menyebabkan usahanya tidak dapat lagi berjalan seperti biasanya, maka pihak BMT Insani Sadabuan melakukan suplai dana kepadanya dengan tujuan supaya ia bisa bangkit kembali sehingga mampu untuk melunasi kewajibannya untuk seterusnya.

Memberikan modal Qardul Hasan, Suplai dana yang diberikan adalah dana pinjaman yang berbentuk Qardul Hasan, dengan tujuan agar anggota dapat menjalankan usahanya kembali seperti biasanya untuk memperoleh keuntungan target sesuai dengan yang diharapkan. Pihak BMT Insani Sadabuan memberikan modal berbentuk Qardul Hasan sebab Qardul Hasan itu bertujuan untuk saling tolong menolong. Harapan BMT Insani Sadabuan memberikan modal pinjaman kepada nasabah yang telah jelas pembiayaannya bermasalah yaitu untuk menolong anggota dalam perekonomiannya agar dapat mempertahankan kehidupannya, karena tujuan dari BMT Insani Sadabuan ini untuk mensejahterakan masyarakat. Selain dari itu tujuan BMT Insani Sadabuan memberikan kembali modal untuk anggota yang mengalami pembiayaan bermasalah dengan maksud agar anggota tersebut mampu berusaha lagi untuk melunasi kewajibankewajibannya tersebut.

Pembinaan Kepada Anggota, strategi penanganan pembiayaan bermasalah yang dilakukan pihak BMT Insani Sadabuan dengan cara memberi pembinaan kepada Anggota. Untuk mengetahui kendala penyebab anggota yang termasuk dalam kategori pembiayaan bermasalah. BMT Insani Sadabuan memberikan pembinaan yang tegas untuk berusaha sebaik-baiknya dalam menjalankan usahanya, karena pelunasan kewajiban untuk BMT Insani Sadabuan tersebut sangatlah penting. BMT Insani Sadabuan selalu memberikan modal kepada anggotanya meskipun anggotanya sudah tergolong dalam pembiayaan bermasalah, dengan harapan anggotanya dapat melunasi semua kewajiban-kewajiban sehingga BMT Insani Sadabuan terhindar dari kerugian. Menurut hasil wawancara peneliti dengan Ibu Elfi S Harahap, Bendahara BMT Insani Sadabuan mengatakan "Pembinaan yang dilakukan kepada anggota misalnya, pihak BMT Insani Sadabuan langsung menanyakan apa kendala yang dihadapi oleh anggota serta memberikan peringatan untuk berusaha semaksimal mungkin agar dapat melunasi kewajibannya, dan pihak BMT Insani Sadabuan memberikan solusi untuk menghindari pembiayaan bermasalah tersebut.

Penjadwalan Kembali, strategi penanganan pembiayaan bermasalah ini dilakukan agar anggota pembiayaan dapat melunasi kewajiban-kewajiban yang diberikan kepadanya. Dengan 
101 Analisis Strategi Penanganan Pembiayaan Bermasalah Di Baitul Mal Wat Tamwil (B M T) Insani Sadabuan

cara meringankan anggota agar benar-benar mampu melunasi kewajibannya. Misalnya menurut hasil wawancara peneliti dengan Ibu Elfi S Harahap, Bendahara BMT Insani Sadabuan mengatakan bahwa hal ini dilakukan dengan cara "Apabila anggota yang biasanya membayar kewajibannya Rp. 25.00o/hari mengalami permasalahan pembiayaan, maka ia diberikan penjadwalan kembali dengan cara, yang biasanya Rp. 25.00o/hari, menjadi misalnya Rp. 20.000/hari, ataupun tergantung kemampuan anggota dalam membayarnya, dengan tujuan agar anggota dapat melunasi segala kewajiban yang diberikan kepadanya”.

\section{KESIMPULAN}

Dari hasil penelitian yang dilakukan oleh peneliti di Baitul Mal Wat Tamwil (BMT) Insani Sadabuan Kota Padangsidimpuan maka peneliti menyimpulkan proses pelaksanaan pembiayaan di Baitul Mal Wat Tamwil (BMT) Insani Kota Padangsidimpuan dimulai dengan petugas pada BMT Insani Sadabuan yang memberikan pelayanan kepada para nasabahnya. Adapun syaratsyarat melakukan pembiayaan pada BMT Insani Sadabuan Kota yaitu: bertempat tinggal di kota Padangsidimpuan dibuktikan dengan KTP asli yang masih berlaku, harus menjadi anggota minimal 5 bulan, menyerahkan agunan atau jaminan atas nama pinjaman, Disetujui suami atau istri dengan menyerahan foto copy KTP suami istri masing-masing sebanyak dua lembar, batas maksimal pinjaman sebesar Rp. 10.000.000,-, batas waktu pinjaman maksimal 24 bulam atau 2 tahun, bagi hasil pinjaman 2,5\% perbulan, apabila terjadi pengambilan pokok pinjaman sebelum habis jangka waktu maka sisa pinjaman tidak dibungakan, menyerahkan pas photo $3 \times 4$ sebanyak 2 lembar, keterlambatan pembayaran cicilan dikenakan denda $2 \%$ dari cicilan, menandatangani seluruh pinjaman. Faktor penyebab terjadinya pembiayaan bermasalah di Baitul Mal Wat Tamwil (BMT) Insani Sadabuan Kota Padangsidimpuan adalah disebabkan faktor internal yang berasal dari pihak BMT Insani Sadabuan. Adapun faktor yang berasal dari pihak BMT Insani Sadabuan yaitu kurangnya pengawasan yang dilakukan oleh pihak BMT Insani Sadabuan, dan kurangnya SDM (Sumber Daya Manusia) yang khusus untuk mengatur pembiayaan anggota. Dan faktor eksternal yang berasal dari anggota pembiayaan. Adapun faktor yang berasal dari anggota pembiayaan yaitu faktor ekonomi yang disebabkan karena pendapatan anggota yang tidak tetap, faktor cuaca yang menyebabkan anggota tidak lancar dalam menjalani usahanya, faktor musibah yang tidak dapat di prediksi kedatangannya yang menyebabkan keterpurukan bagi anggota. Sedangkan, penanganan pembiayaan bermasalah di BMT Insani Sadabuan Kota Padangsidimpuan dengan cara: penagihan yaitu dengan melalui via telepon, penagihan langsung JISFIM: Journal of Islamic Social Finance Management, Volume 1, No 1 Tahun 2020 http://jurnal.iain-padangsidimpuan.ac.id/index.php/JISFIM 
ke lokasi nasabah, memberikan modal berbentuk Qardul Hasan, Pembinaan kepada anggota pembiayaan, dan penjadwalan kembali. Baitul Mal Wat Tamwil (BMT) Insani Sadabuan Kota Padangsidimpuan harus tetap mempertahankan fungsinya sebagai institusi yang terus berikhtiar untuk membantu masyarakat dalam bermuamalah karena Allah Ta'ala, Baitul Mal Wat Tamwil (BMT) Insani Sadabuan Kota Padangsidimpuan juga harus tetap meningkatkan kualitas kinerjanya khususnya agar fokus, cermat, dan teliti lagi agar mencegah terjadinya pembiayaan yang bermasalah.

\section{DAFTAR PUSTAKA}

Ali, Zainuddin Hukum Perbankan Syariah, Jakarta: Sinar Grafika, 2008.

Al-Muntaqimu, Al-Qur'an dan Terjemahannya, Semarang: PT Karya Toha Putra.

Arikunto, Suharsimi, Prosedur Penelitian Suatu Pendekatan, Jakarta: PT. Rineka Cipta, 2002. Bungin, Burhan, Analisis Data Penelitian Kualitatif, Jakarta: PT Raja Grafindo Persada, 2003. Djamil, Faturrahman, Penyelesaian Pembiayaan Bermasalah di Bank Syariah, Jakarta: Sinar Grafika, 2012.

Gusfahmi, Pajak menurut Syariah, Jakarta: PT Raja Grafindo Persada, 2007.

Huda, Nurul dkk, Baitul Mal Wa Tamwil, Jakarta: Amzah, 2016.

Ibrahim, Azharsyah \& Arinal Rahmati, “Analisis Solutif Penyelesaian Pembiayaan Bermasalah di Bank Syariah: Kajian Pada Produk Murabahah di Bank Muamalat Indonesia Banda Aceh”, Jurnal Fakultas Ekonomi dan Bisnis Islam UIN Ar-Raniry Banda Aceh, Volume 10, No. 1, tahun 2017.

Ikatan Bankir Indonesia, Memahami Bisnis Bank, Jakarta: PT Gramedia Pustaka Utama, 2013. ,Mengelola Bisnis Pembiayaan Bank Syariah, Jakarta: PT. Gramedia Pustaka Utama, 2015.

Ismail, Perbankan Syariah, Jakarta: Kencana, 2011.

Karangpuang, Nawfalsky Bagis Muhammad, "Strategi Penanganan Pembiayaan Murabahah Bermasalah pada Baitul Mal Wat Tamwil (BMT) Mekar Da'wah”, Skripsi UIN Syarif Hidayatullah Jakarta, 2017.

Kasmir, Dasar-Dasar Perbankan, Jakarta: PT Raja Grafindo Persada, 2008. ,Manajemen Perbankan, Jakarta: Rajawali, 2000.

Kholil, Syukur, Metodologi Penelitian Komunikasi, Bandung: Citapustaka Media, 2006.

Komalasari, Desi, "Implementasi Manajemen Resiko Pembiayaan Murabahah dalam Upaya Meminimalisir NPF (Non Performing Financing) pada Divisi Mikro Bank Muamalat Indonesia Cabang Cirebon”, Skripsi IAIN Syekh Nurjati Cirebon, 2016.

JISFIM: Journal of Islamic Social Finance Management, Volume 1, No 1 Tahun 2020 http://jurnal.iain-padangsidimpuan.ac.id/index.php/JISFIM 
103 Analisis Strategi Penanganan Pembiayaan Bermasalah Di Baitul Mal Wat Tamwil (B M T) Insani Sadabuan

Kurniawan, Endra, "Strategi Penanganan Pembiayaan Bermasalah di Baitul Maal Wa Tamwil Usaha Gabungan Terpadu Sidogiri Kantor Cabang Lodoyo Blitar”, Skripsi IAIN Tulungagung, 2017.

Moleong, Lexy J, Metodologi Penelitan Kualitatif, Bandung: PT Remaja Rosdakarya, 2004.

Mulyana, Dedy, Metode Penelitian Kualitatif, Yogyakarta: Pustaka Pelajar, 2006.

Nasution S, Metode Research, Jakarta: Bumi Aksara, 2003.

Nilasari, Senja, Manajemen Strategi itu Gampang, Jakarta: Dunia Cerdas, 2014.

Nornita, Lucky Megalia , “Analisis Tingkat Kesehatan Lembaga Keuangan Syariah Studi pada BMT Bina Ihsanul Fikri Tahun 200o-2011”, Skripsi, UIN Sunan Kalijaga, Yogyakarta, 2012.

Perwataatmadja, Karnaen dan Muhammad Syafi'i Antonio, Apa dan Bagaimana Bank Islam, Yogtakarta: Dana Bhakti Wakaf, 1992.

Rodoni, Ahmad \& Abdul Hamid, Lembaga Keuangan Syariah, Jakarta: Zikrul Hakim, 2007.

Salman, Kautsar Riza, Akuntansi Perbankan Syariah, Jakarta: Akademia Permata, 2012.

Sastraprada, M, Kamus Istilah Pendidikan dan Umum, Surabaya:Usaha Nasional, 1981.

Shihab, M. Quraish Tafsir Al-Mishbah Pesan, Kesan dan Keserasian Al-Qur'anVolume 5, Jakarta: Lentera Hati, 2002.

,Tafsir Al-Mishbah Pesan, Kesan dan Keserasian Al-Qur'anVolume 12, Jakarta: Lentera Hati, 2002.

, Tafsir Al-Mishbah Pesan, Kesan dan Keserasian Al-Qur'an Volume 2 , Jakarta: Lentera Hati, 2002.

, Tafsir Al-Mishbah Pesan, Kesan dan Keserasian Al-Qur'an Volume 1 , Jakarta: Lentera Hati, 2002.

, Tafsir Al-Mishbah Pesan, Kesan dan Keserasian Al-Qur'an Volume 14, Jakarta: Lentera Hati, 2002.

Soemitra, Andri, Bank dan Lembaga Keuangan Syariah, Jakarta: Kencana, 2009. Ascarya, Akad dan Produk Bank Syariah, Jakarta: Rajawali Perss, 2013.

Suhendi, Hendi, Fiqh Muamalah, Jakarta: Rajawali Pers, 2010.

Surin, Bachtiar, Adz-Dzikraa terjemahan \& tafsir Al Quran dalam huruf Arab \& Latin juz 1-5, Bandung: Offest Angkasa, 1991.

Wangsawidjaja, Pembiayaan Bank Syariah, Jakarta: PT Gramedia Pustaka Utama, 2012.

Wirdyaningsih dkk, Bank dan Asuransi Islam di Indonesia, Jakarta: Kencana, 2007.

Zulkifli, Sunarto, Panduan Praktis Transaksi Perbankan Syariah, Jakarta: Zikrul Hakim, 2000.

Zuriah, Nurul, Metodologi Penelitian Sosial dan Pendidikan, Jakarta: PT. Bumi Aksara, 2006.

JISFIM: Journal of Islamic Social Finance Management, Volume 1, No 1 Tahun 2020

http://jurnal.iain-padangsidimpuan.ac.id/index.php/JISFIM 